\title{
Kemampuan Mengecap Phenylthiocarbamide (PTC) dan Distribusi Golongan Darah Sistem ABO pada Mahasiswa Fakultas Kedokteran Universitas YARSI Angkatan 2019
}

\section{The Ability to Taste Phenylthiocarbamide (PTC) and the Distribution of ABO System Blood Type: A Case Study of Medical Students at YARSI University Class of 2019}

\author{
Endang Purwaningsih, Etty Widayanti, Mirfat \\ Department of Anatomy, Faculty of Medicine, YARSI University, Jakarta \\ Menara YARSI, Kav 13. Jl Let. Jend. Soeprapto, Cempaka Putih, Jakarta Pusat 10510 \\ E-mail: endang.purwaningsih@yarsi.ac.id
}

KATA KUNCI PTC; tester; non tester; ABO; mahasiswa

\begin{abstract}
ABSTRAK
Kemampuan mengecap PTC seseorang dapat berguna dan penting untuk mempelajari keragaman genetik pada populasi manusia. Sensitivitas rasa PTC penting dalam pemilihan makanan. Golongan darah ABO merupakan sistem darah yang penting dalam klinis, genetik, dan antropologi. Tujuan penelitian adalah mengetahui frekuensi tester dan genotipnya pada mahasiswa Fakultas Kedokteran Universitas YARSI Tahun Akademik 2019 dihubungkan dengan golongan darah sistem ABO. Metode penelitian adalah eksperimental dengan rancangan cross sectional. Tes PTC dilakukan menggunakan kertas lakmus PTC. Data golongan darah diperoleh dari kuisioner. Hasil penelitian menunjukkan bahwa dari 213 mahasiswa didapatkan mahasiswa tester sebanyak 153 dan nontester sebanyak 60. Diantara mahasiswa tester sebagian besar berjenis kelamin perempuan. Frekuensi gen t sebesar 0,5306 dan frekuensi gen T sebesar 0,4694. Mahasiswa bergolongan darah $\mathrm{O}$ paling tinggi dan golongan $\mathrm{AB}$ paling rendah. Berdasarkan kemampuan mengecap rasa pahit (tester/ non tester) dan jenis kelamin, frekuensi tertinggi adalah golongan darah $\mathrm{O}$ pada laki-laki tester dan perempuan non tester, sedangkan frekuensi terendah adalah golongan AB pada laki-laki non tester. Disimpulkan bahwa kemampuan mengecap PTC mahasiswa Fakultas Kedokteran Universitas YARSI Angkatan 2019 memiliki insidensi testernya tinggi dan didominasi mahasiswa perempuan. Distribusi frekuensi golongan darah $\mathrm{O}$ paling tinggi dan golongan darah $\mathrm{AB}$ paling rendah pada lakilaki tester dan perempuan non tester.
\end{abstract}


KEYWORDS

ABSTRACT
PTC; taster; non-taster; ABO; students

The ability to taste a person's PTC can be useful and important for studying genetic diversity in human populations. PTC taste sensitivity is essential in food selection. ABO blood type is an important blood system in clinical, genetic, and anthropological studies. The study aimed to determine the frequency of the tester and its genotypes in students of the Faculty of Medicine, YARSI University Academic Year 2019 , related to the ABO system blood type. The research method was experimental with a cross-sectional design. The PTC test is performed using a PTC litmus paper. Blood group data were obtained from questionnaires. The results showed that from 213 students, 153 taster students and 60 non-tasters were found. Most of the tester students were female. The $t$ gene frequency was 0.5306 and the $T$ gene frequency was 0.4694 . Students with blood type $O$ are the most common and group $A B$ is the least common. Based on the ability to taste bitter taste (taster/nontaster) and gender, the highest frequency was blood group $O$ for male taster and female non-taster, while the lowest frequency was group $A B$ for non-taster men. We concluded that the ability to taste PTC of YARSI University Faculty of Medicine students of 2019 had a high tester incidence and was dominated by female students. The frequency distribution of blood type $O$ was highest and blood group $A B$ was lowest in male tasters and non-taster women.

\section{PENDAHULUAN}

Persepsi rasa phenylthiocarbamide (PTC) adalah sifat yang dikendalikan secara genetik dan bervariasi dari satu populasi manusia ke populasi lainnya. Gen yang bertanggung jawab untuk fenotipe ini dipetakan pada lengan $q$ kromosom 7 pada manusia. Phenylthiocarbomide (PTC) merupakan senyawa untuk mengetahui kapasitas sensor perasa pada lidah, yang dalam suatu populasi, sekolompok orang digolongkan sebagai tester dan sekelompok lainnya digolongkan sebagai non tester. Tester merupakan orang yang mampu merasakan pahit PTC sedangkan non-tester merupakan orang yang tidak bisa merasakan pahit PTC (Igbenehu et al., 2017).

Adanya gen PTC pada lidah, yaitu gen TAS2Rs akan mempengaruhi pemilihan makanan, status gizi atau metabolisme tiroid. Sebagai contoh sebagian orang beranggapan kalau Brokoli (Brassica oleracea) terlalu pahit untuk dikonsumsi sedangkan sebagian lain beranggapan brokoli tidak pahit (Sausenthaler et al., 2009). Gen PTC tidak menjadi penyebab sepenuhnya dalam merasakan pahit, tetapi terdapat faktorfaktor lain misalnya kebiasaan makan dan minum. Makanan minuman panas dan pedas menyebabkan kesensitivan lidah berkurang.

Sifat merasakan pahit PTC ini merupakan sebuah contoh sifat Mendel sederhana yaitu satu gen dominan dalam dua alel. Penemuan terbaru melaporkan adanya lokus besar pada kromosom 5p15 dan lokus tambahan pada kromosom 7.q34 (Grimm and Steinle, 2011). 
Kemampuan merasakan pahit PTC disebabkan adanya alel dominan $\mathrm{T}$, sedangkan ketidak mampuan merasakan pahit PTC disebabkan alel resesif t. Parental ayah TT jika menikah dengan ibu tt akan menghasilkan keturunan Tt. TT merupakan tester, tt merupakan nontester, dan $\mathrm{Tt}$ merupakan tester. Pengalaman rasa pahit terjadi setelah zat kimia tertentu berkontak dengan reseptor pengecap yang terletak pada sel di permukaan lidah (Fareed et al., 2012).

Golongan darah ABO dan Rhesus (Rh) merupakan sistem darah yang paling sering diteliti pada populasi manusia untuk kepentingan klinis, genetik, dan antropologi. Sistem golongan darah ABO adalah sifat yang paling banyak dipelajari dalam genetika manusia diikuti oleh kemampuan untuk mencicipi feniltiokarbamid (PTC). Kedua sifat ini digunakan secara luas dalam mendeskripsikan variasi genetik pada populasi manusia di seluruh dunia. Sistem golongan darah ABO diekspresikan oleh 3 alel pada kromosom 9 yang mengontrol 4 fenotipe, yaitu A, B, AB dan $\mathrm{O}$. Sedangkan sistem Rh kompleks secara genetik dan dideskripsikan sebagai pasangan tunggal alel, D dan d, pada kromosom 1, mengendalikan 2 fenotipe, $\mathrm{Rh}$ positif $(\mathrm{Rh}+)$ dan $\mathrm{Rh}$ negatif ( $\mathrm{Rh}-$ ). Pengelompokan $\mathrm{ABO}$ dan faktor $\mathrm{Rh}$ dalam kelompok darah didasarkan pada sifat antigenik pada permukaan membran eritrosit (Alimba et al., 2017).

Tujuan penelitian adalah mengetahui frekuensi tester dan non tester pada mahasiswa Fakultas Kedokteran Universitas YARSI Tahun Akademik 2019 dengan frekuensi genotipnya serta dikaitkan dengan golongan darah sistem ABO.

\section{METODOLOGI}

Waktu penelitian adalah antara bulan Nopember - Desember 2019, dengan subyek penelitian, mahasiswa Fakultas Kedokteran FK UY angkatan 2019 yang telah mengisi informed consent.

\section{Jenis Penelitian}

Jenis penelitian adalah penelitian eksperimental dengan rancangan cross sectional. Pengambilan sampel dilakukan dengan teknik random sampling. Populasi adalah mahasiswa Fakultas Kedokteran Universitas YARSI Angkatan 2019. Sampel adalah mahasiswa FK angkatan 2019 yang memiliki kriteria inklusi: mahasiswa tidak memiliki kelainan sistemik pada saat penelitian, tidak ada luka pada lidah, tidak menggunakan obat kumur. Sedangkan kriteria eksklusi adalah mahasiswa yang memiliki kelainan sistemik pada saat penelitian, ada luka pada lidah dan menggunakan obat kumur.

\section{Bahan Penelitian}

Digunakan bahan uji PTC berupa kertas lakmus untuk phenyl thiocarbamide (Precision Laboratory).

\section{Cara Kerja}

Subyek diintruksikan untuk berkumur dengan aquades, kemudian meludah beberapa kali sampai tidak ada sisa aquades yang tertinggal di dalam mulutnya. Kemudian subyek diinstruksikan untuk menjulurkan lidahnya, selanjutnya dikeringkan dengan cotton roll untuk mencegah pengaruh saliva. Kertas lakmus phenylthiocarbamide ditempelkan di bagian tengah lidah. Setelah itu, subyek ditanya, apa yg dia rasakan, pahit atau tidak pahit. Jika subyek merasakan pahit, dikelompokkan sebabagai pengecap 
(tester) dan jika tidak merasakan rasa pahit, dikelompokkan sebagai buta kecap (non tester).

Data golongan darah diperoleh dari hasil kuisioner.

ISI

Hasil penelitian menunjukkan frekuensi tester dan non tester berbeda. Ada kecenderungan lebih banyak tester pada mahasiswa FK Universitas YARSI angkatan 2019 dibandingkan non tester (Tabel 1).

Dari total populasi mahasiswa Fakultas Kedokteran Universitas YARSI sebanyak 213 orang, didapatkan non tester sebanyak 60 orang (genotip tt) dan sebanyak 153 orang adalah tester (genotip TT atau Tt). Menurut Hukum Hardy Weinberg, frekuensi gen $\mathrm{T}$ dan $\mathrm{t}$ adalah sebagai berikut: $\mathrm{p}^{2}+2 \mathrm{pq}+\mathrm{q}^{2}=1(\mathrm{p}=$ gen dominan $\mathrm{T}$ dan $\mathrm{q}=$ gen resesif $\mathrm{t}$ ). Dari rumus di atas didapatkan $\mathrm{q}$ (frekuensi gen t) adalah sebesar 0,5306 dan $\mathrm{p}$ (frekuensi gen T) adalah sebesar 0,4694. Dalam hal ini seorang tester bisa bergenotip homozigot dominan TT atau heterozigot $\mathrm{Tt}$, sedangkan non tester selalu bergenotip homozigot resesif tt.

Berdasarkan golongan darah sistem ABO mahasiswa FK Universitas YARSI Angkatan 2019 menunjukkan golongan darah $\mathrm{O}$ memiliki insidensi paling tinggi $(34,20 \%)$ dan golongan $\mathrm{AB}$ memiliki insidensi paling rendah $(10,80)$. Sedangkan insidensi tester dan non tester berdasarkan golongan darah sistem ABO, yaitu golongan $\mathrm{O}, \mathrm{A}, \mathrm{B}$ dan $\mathrm{AB}$ cukup bervariasi mulai dari $0,93 \%$ sampai $15,9 \%$ seperti yang tersaji pada Tabel 2 .

Tabel 1. Insidensi tester dan non tester mahasiswa FK Universitas YARSI Angkatan 2019 berdasarkan jenis kelamin

\begin{tabular}{ccccc}
\hline Total & \multicolumn{2}{c}{ Taster } & \multicolumn{2}{c}{ Non-taster } \\
213 & $\mathrm{~N}=153$ & $\mathrm{~N}=60$ \\
\cline { 2 - 5 } & Laki-laki & Perempuan & Laki-laki & Perempuan \\
\hline Jumlah & 47 & 106 & 13 & 47 \\
Insidensi & 22,06 & 49,76 & 6,10 & 22,06 \\
\hline
\end{tabular}

Tabel 2. Insidensi tester dan non tester pada mahasiswa FK Universitas YARSI Angkatan 2019 berdasarkan golongan darah sistem ABO

\begin{tabular}{cccccc}
\hline \multirow{2}{*}{$\begin{array}{c}\text { Golongan } \\
\text { Darah }\end{array}$} & \multirow{2}{*}{$\begin{array}{c}\text { Jumlah } \\
(\text { Insidensi } \%)\end{array}$} & $\begin{array}{c}\text { Laki-laki } \\
\text { (Insidensi \%) }\end{array}$ & $\begin{array}{c}\text { Perempuan } \\
(\text { Insidensi \%) }\end{array}$ & $\begin{array}{c}\text { Laki-laki } \\
(\text { Insidensi \%) }\end{array}$ & $\begin{array}{c}\text { Perempuan } \\
(\text { Insidensi \%) }\end{array}$ \\
\hline $\mathrm{O}$ & $73(34,20)$ & $22(10,3)$ & $26(12,2)$ & $3(1,40)$ & $22(10,30)$ \\
$\mathrm{A}$ & $52(24,40)$ & $8(3,75)$ & $31(14,50)$ & $3(1,40)$ & $10(4,70)$ \\
$\mathrm{B}$ & $65(3050)$ & $14(6,57)$ & $34(15,90)$ & $5(2,34)$ & $12(5,63)$ \\
$\mathrm{AB}$ & $23(10,80)$ & $3(1,40)$ & $15(7,04)$ & $2(0,93)$ & $3(1,40)$ \\
\hline Total & 213 & 47 & 106 & 13 & 47 \\
\hline
\end{tabular}


Sensasi rasa yang berasal dari stimulasi pengecap pada lidah secara klasik tersegmentasi ke dalam kategori yang berbeda, terutama yang banyak dikenal yaitu manis, asam, pahit, dan asin (Richard et al, 2017). Kemampuan untuk mengecap PTC sebagai sensasi rasa pahit oleh seseorang dianggap sebagai alat yang berguna dan penting untuk mempelajari keragaman genetik pada populasi manusia. Persepsi rasa PTC telah digunakan sebagai alat untuk melacak garis keturunan (lineage) keluarga dan pola migrasi populasi. Sebelumnya, kemampuan mengecap PTC ini digunakan dalam uji paternitas sebelum munculnya penanda DNA (Igbenehu et al, 2017). Di samping kepentingannya dalam studi genetik dan antropologi, sensitivitas rasa PTC terbukti penting dalam pemilihan makanan, yang dapat mempengaruhi metabolisme dan fisiologi seseorang Kemampuan atau ketidakmampuan untuk mengecap PTC juga telah dilaporkan adanya hubungan antara kemampuan mengecap PTC dengan sejumlah penyakit, seperti diabetes, penyakit mata, penyakit tiroid, ulkus salura cerna, dan kerentanan terhadap penyakit infeksi (Alimba et al, 2017).

Persepsi rasa pahit dimediasi oleh reseptor dari subfamili ATAS2R pada membran sel yang berpasangan dengan protein G. Senyawa pahit akan berikatan dengan reseptor ATAS2 R. Gen reseptor ini berperan penting dalam mengubah rasa kimia secara rasional. Hal ini berguna untuk menghindari berbagai senyawa yang bersifat racun (Biarnes et al., 2010).

Dari hasil penelitian didapatkan bahwa dalam populasi mahasiswa FK Universitas YARSI angkatan 2019 menunjukkan insidensi tester lebih tinggi dibandingkan dengan non tester yaitu lebih dari dua kalinya bahkan hampir tiga kalinya dibandingkan non tester. Kemampuan mencicipi PTC bukan hanya salah satu dari banyak sifat manusia yang tampaknya tidak berbahaya (seperti kemampuan menggulung lidah atau melipat lengan) tetapi tidak menjadi dasar dari variabilitas genetiknya. Kebutaan rasa PTC dilaporkan berhubungan dengan preferensi makanan dan beberapa penyakit, terutama gangguan metabolisme tiroid (Guo and Reed, 2001).

Perbedaan antar individu dalam respon rasa pahit berasal dari variasi alel atau haplotipe antar individu. Terkait dengan perbedaan individual dalam sensitivitas rasa pahit ini, ditemukan bahwa subyek yang berusia lebih muda, lebih sensitif dibandingkan subyek yang berusia lebih tua terhadap rasa pahit PTC, karena usia memodifikasi hubungan genotipe-fenotipe. Heterozigositas meningkatkan sensitivitas terhadap PTC, yaitu, anak yang bergenotip heterozigot, akan mengecap rasa pahit pada konsentrasi yang lebih rendah disbandingkan orang dewasa dengan genotipe homozigot. Penelitian tersebut menunjukkan, bahwa genotipe heterozigot (Tt) PTC lebih sering ditemukan dibandingkan dengan genotipe homozigot dominan (TT) dan resesif (tt) (Fareed et al., 2012).

Dari penelitian sebelumnya ditemukan ada keluarga yang anggota keluarganya menganggap rasa PTC lebih manis daripada pahit. Hal ini karena PTC secara struktural mirip dengan senyawa Dulcin, yang sangat manis dan ini terjadi karena adanya mutasi reseptor PTC dan merespons PTC sebagai sesuatu yang manis daripada pahit. Adanya polimorfisme PTC ini, mungkin bukan akibat kurangnya reseptor sel rasa, melainkan kurangnya senyawa dalam air liur yang memungkinkan orang untuk merasakan PTC (Guo \& Reed, 2001). 
Berdasarkan jenis kelamin, hasil penelitian menunjukkan insidensi tester lebih besar pada perempuan dibandingkan laki-laki atau dapat dikatakan bahwa insidensi tester lebih pada perempuan dari pada laki-laki. Dari penelitian-penelitian sebelumnya dilaporkan bahwa hampir semua penelitian menunjukkan kecenderungan perempuan untuk menjadi pencicip/tester yang sensitif dibandingkan dengan laki-laki baik pada anak-anak atau remaja. Hal ini mungkin disebabkan sensitivitas PTC dapat berubah selama siklus menstruasi dan hormon seks pada perempuan dapat memengaruhi sensitivitas PTC (Guo \& Reed, 2001).

Dengan kata lain secara proporsional, laki-laki lebih sering ditemukan sebagai non tester dibandingkan perempuan, dan sebaliknya perempuan lebih sering ditemukan sebagai tester dibandingkan laki-laki. Hal ini sesuai dengan penelitian sebelumnya oleh Alimba et al, 2017). Sensitivitas PTC diwariskan melalui gen autosomal dengan pewarisan Mendel, dengan tester merupakan sifat dominan (T) dan nontester resesif $(\mathrm{t})$. Sensitivitas PTC selain penting dalam studi genetik dan antropologi, sensitivitas rasa PTC juga terbukti berperan penting dalam pemilihan makanan, yang dapat mempengaruhi metabolisme dan fisiologi seseorang. Kemampuan atau ketidakmampuan untuk mengecap PTC juga telah dilaporkan untuk menunjukkan hubungan dengan sejumlah penyakit, seperti diabetes, penyakit mata, penyakit tiroid, ulkus saluran cerna, dan kerentanan terhadap penyakit infeksi (Alimba et al, 2017).

Dalam beberapa kasus dilaporkan bahwa laki-laki ditemukan lebih banyak sebagai tester dari pada perempuan. Kadang-kadang pada kasus kembar identik tidak sama dalam kemampuan mereka mencicipi dan karena itu pengaruh lingkungan, seperti penyakit, dapat mengubah status pencicip atau tester (Guo \& Reed, 2001).

Peneliti lain juga melaporkan, bahwa perempuan lebih sering memiliki fenotipe PTC tester dibandingkan lakilaki. Ambang batas rasa PTC populasi perempuan ditemukan dapat merasakan pahitnya PTC pada ambang batas yang lebih rendah dibandingkan laki-laki, (Fareed et al., 2012). Diduga lokus pengubah yang meningkatkan sensitivitas rasa PTC terletak pada kromosom $\mathrm{X}$ atau mungkin gen autosom yang diatur oleh hormon seks. Selain jenis kelamin, merokok dan penuaan dapat menjadi pengubah lain dari hubungan fenotip dan genotipe PTC (Guo \& Reed, 2001).

Golongan darah $\mathrm{ABO}$ dan $\mathrm{Rh}$ merupakan sistem golongan darah yang paling sering diteliti pada populasi manusia untuk kepentingan klinis, genetik, dan antropologi. Sementara golongan darah ABO diekspresikan oleh 3 alel pada kromosom 9 yang mengontrol 4 fenotipe: $\mathrm{A}, \mathrm{B}, \mathrm{AB}$ dan $\mathrm{O}$, sedangkan sistem $\mathrm{Rh}$ dideskripsikan sebagai pasangan tunggal alel, D dan d, pada kromosom nomor 1 yang mengendalikan 2 fenotipe, yaitu $R h$ positif $(R h+)$ dan $R h$ negatif ( $\mathrm{Rh}-)$. Pengelompokan ABO dan faktor $\mathrm{Rh}$ dalam kelompok darah didasarkan pada sifat antigenik pada permukaan membran eritrosit (Alimba et al, 2017).

Dari hasi pada Tabel 2, diketahui bahwa diantara ke empat golongan darah sistem $\mathrm{ABO}$ frekuensi/insidensi tertinggi adalah golongan 0 dan terendah golongan AB. Pola frekuensi golongan darah sistem ABO pada populasi mahasiswa Kedokteran Universitas YARSI Angkatan 2019 adalah golongan $\mathrm{O}>\mathrm{B}>\mathrm{A}>\mathrm{AB}$. Sedangkan frekuensi golongan darah ABO berdasarkan kemampuan mengecap rasa pahit (tester/ non tester) dan jenis 
kelamin adalah untuk laki-laki tester $\mathrm{O}>\mathrm{B}$ $>\mathrm{A}>\mathrm{AB}$, perempuan tesrter $\mathrm{B}>\mathrm{A}>\mathrm{O}>\mathrm{AB}$, laki-laki non tester $\mathrm{B}>\mathrm{O}=\mathrm{A}>\mathrm{AB}$, dan perempuan non tester adalah $\mathrm{O}>\mathrm{B}>\mathrm{A}>\mathrm{AB}$. Belum diketahui hubungan antara sensitivitas rasa pahit PTC dengan golongan darah.

Berbeda dengan hasil penelitian ini, penelitian sebelumnya dari Universitas Delhi di India didapatkan presentase tester tertinggi ditemukan pada golongan $\mathrm{AB}$, terendah pada golongan $\mathrm{B}$; sedangkan presentase non tester tertinggi ditemukan pada golongan B dan terendah pada golongan AB. Berdasarkan kemampuan sekretor dan golongan darah didapatkan bahwa tester sekretor tertinggi ditemukan pada golongan A dan terendah pada golongan B. Sebaliknya pada non tester non sekretor persentase tertinggi adalah golongan A dan terendah adalah golongan O (Bathia et al., 1979) .

Peneliti lain melaporkan, bahwa golongan darah $\mathrm{O}$ memiliki frekuensi persentase tertinggi pada perempuan dan laki-laki yang diperiksa, tetapi dengan laki-laki memiliki frekuensi yang lebih tinggi dibandingkan perempuan (lakilaki $=71.98 \%$ dan perempuan $=62.27 \%$ ) . Meskipun frekuensi persentase golongan darah $\mathrm{AB}$ paling rendah pada laki-laki dan perempuan, tetapi laki-laki $(2.16 \%)$ lebih rendah dibandingkan perempuan $(4.09 \%)$. Golongan darah A dan B memiliki frekuensi yang sama pada laki-laki, tetapi frekuensi tersebut lebih rendah pada perempuan. Frekuensi persentase golongan B lebih tinggi dibandingkan golongan A pada perempuan. Frekuensi alel yang ditemukan untuk laki-laki dan perempuan menunjukkan pola serupa untuk nilai keseluruhan. (Alimba et al., 2017).

Pada populasi mahasiswa Fakultas Kedokteran YARSI angkatan 2019 insidensi tertinggi adalah sebagai tester dan bejenis kelamin perempuan. Golongan darah terbanyak adalah golongan darah $\mathrm{O}$. Insidensi golongan darah tertinggi dari laki-laki tester adalah golongan darah $\mathrm{O}$ sedangkan perempuan tester golongan darah B. Sebaliknya untuk kelompok non tester, insidensi tertinggi untuk laki-laki nontester adalah golongan darah B sedangkan perempuan non tester adalah golongan darah $\mathrm{O}$.

\section{PENUTUP}

Kemampuan mengecap PTC mahasiswa Fakultas Kedokteran Universias YARSI Angkatan 2019 memiliki insidensi testernya tinggi dan didominasi mahasiswa perempuan. Distribusi frekuensi golongan darah $\mathrm{O}$ paling tinggi dan golongan darah $\mathrm{AB}$ paling rendah pada laki-laki tester dan perempuan non tester.

Perlu dilakukan penelitian lebih lanjut untuk mengetahui ada hubungannya antara kemampuan mengecap PTC dengan indeks massa tubuh.

\section{DAFTAR PUSTAKA}

Alimba CG, Oboh B, Adekoya A (2010). Prevalence and gene frequencies of phenylthiocarbamide (PTC) taste, sensitivity, $\mathrm{ABO}$ and Rhesus (Rh) blood groups, and haemoglobin variants among Nigerian population. Egypt J Med Hum Gen 11: 153- 158

Bathia, S. Sharma KN, Tandon OP, Singh S. (1979). Relation of PTC Responses and Secretor Status to Blood Groups. Ind $J$ Physiol Pharmac 2 94):269 - 276

Biarnes X, Marchion A, Giorgetti A, Lanzara, Gasparini P, Carioni P, Born S, Brackhof A, Bechren M, Meyerhof W 2010. Insights in to the Binding of Phenyltiocarbamideto its Target Human TAS2RB Bitter Receptor. PLoS One 5 (8): e12394 
Fareed M, Shah A, Hussain R, Afsal L. (2012). Genetic study of phenylthiocarbamide (PTC) taste perception among six human populations of Jammu and Kashmir (India). The Egyptian J of Med Hum Gen 13: 161166.

Grimm ER and Steinle NI. (2011). Genetics of Eating Behavior; Established and Emerging Concepts. Nutr Rev 69 (1): 52 $-60$

Guo SW, Reed DR. (2001). The genetics of phenylthiocarbamide perception. Ann Hum Biol. 2 8:111-114

Igbenehu C, Olesikodiaka JM, Aina OA, Oseni BSA, Oluwathunbi BT. (2017).
PTC Taste Perception In HIV Naïve Person IJHSR 7 (8) ; 87 - 91.

Richard LD, Jonathan J, Chen VH. (2017). Taste Quality Confusions: Influences of Age, Smoking, PTC Taster Status, and other Subject Characteristics. Perception $0(0) ; 1-16$

Shivaprasad HS. Chaithra PT, Kavitha P, Malini SS. (2012). Role of phrnylthiocarbamide as genetic marker in predicting the predisposition of disease traits in human. J Nat Sci Biol Med:43-47 Sausenthaler.S. Rhezak P, Wichman E, Hemrich J. (2009). Lack of Relation Between Bitter Taste Receptor TAS2R38 and BMI in Adults. Perception 7(5): 937 $-938$ 